\title{
Mutation and association analysis of the PVR and PVRL2 genes in patients with non-syndromic cleft lip and palate
}

\author{
Mehmet A. Sözen ${ }^{1,3}$, Jacqueline T. Hecht ${ }^{2}$ and Richard A. Spritz ${ }^{3}$ \\ ${ }^{1}$ Department of Medical Biology, School of Medicine, Afyon Kocatepe University, Afyonkarahisar, Turkey. \\ ${ }^{2}$ Department of Pediatrics, University of Texas Medical School, Houston,Texas, USA. \\ ${ }^{3}$ Human Medical Genetics Program, University of Colorado Denver, Anschutz Medical Campus, Aurora, \\ CO, USA.
}

\begin{abstract}
Orofacial clefts (OFC; MIM 119530) are among the most common major birth defects. Here, we carried out mutation screening of the PVR and PVRL2 genes, which are both located at an OFC linkage region at 19q13 (OFC3) and are closely related to $P V R L 1$, which has been associated with both syndromic and non-syndromic cleft lip and palate (nsCLP). We screened a total of 73 nsCLP patients and 105 non-cleft controls from the USA for variants in PVR and $P V R L 2$, including all exons and encompassing all isoforms. We identified four variants in PVR and five in PVRL2. One non-synonymous $P V R$ variant, A67T, was more frequent among nsCLP patients than among normal controls, but this difference did not achieve statistical significance.
\end{abstract}

Key words: PVR, PVRL2, cleft lip and palate, mutation, SSCP.

Received: September 16, 2008; Accepted: March 28, 2009.

Orofacial clefts (OFC) are common birth defects, occurring in approximately 1 per 800 North American Caucasian infants and varying in incidence among patients of different geographical origins (Vanderas, 1987). Most cases of OFC $(70 \%)$ occur sporadically, and may include isolated cleft lip, cleft lip with or without palate (CLP) and isolated cleft palate. Such 'non-syndromic' OFC appear to be polygenic in origin, a number of loci each exerting a relatively modest effect against a multi-factorial background (Spritz, 2001; Murray, 2002; Cobourne, 2004).

A role for one or more genes at chromosome 19q involved in non-syndromic CLP (nsCLP) has been supported by multiple lines of evidence. Genetic linkage studies defined $O F C 3$, a region of genetic linkage to nsCLP on chromosome 19q13 (Stein et al., 1995; Warrington et al., 2006). Initial studies of candidate genes in the $O F C 3$ region focused on $B C L 3$, a number of genetic association studies finding conflicting evidence of association with nsCLP in various populations (Stein et al., 1995; Amos et al., 1996; Maestri et al., 1997; Gaspar et al., 2002; Blanco et al., 2004). Other genes studied in the OFC3 region include APOC2 (Marazita et al., 2002), CLPTM1 (Yoshiura et al.,1998; Turhani et al., 2005;

Send correspondence to Mehmet A. Sözen, Department of Medical Biology, School of Medicine, Afyon Kocatepe University, 03200 Afyonkarahisar, Turkey. E-mail: masozen@ hotmail.com.
Warrington et al., 2006), and TOMM40 (Warrington et al., 2006), each yielding, at best, inconsistent evidence for involvement in nsCLP.

Recent attention has turned to two other candidate genes in 19q13, PVR and $P V R L 2$, which are paralogous to PVRL1, in which homozygous mutations result in a rare autosomal recessive CLP syndrome, CLPED1 (Suzuki et $a l ., 2000$ ), and in which variants have been genetically associated with nsCLP in northern Venezuela (Sözen et al., 2001) and perhaps other populations (Avila et al., 2006; Scapoli et al., 2006; Tongkobpetch et al., 2008). PVR, $P V R L 1$, and PRVL2 respectively encode Necl-5/CD155, nectin-1 and nectin-2, cell adhesion molecules present at adherens junctions and other ectoplasmic specializations at cell-cell contacts (Young et al., 2009), and are widely expressed during development. Warrington et al. (2006) reported genetic association of a rare intronic variant in PVR, C_1828143_10 (rs35385129), with nsCLP in patients from several different populations, and by direct sequencing identified 7 variants in PVR and 16 in PVRL2, none of which appeared to be causal for nsCLP. A subsequent study found marginal association of nsCLP in Italian patients with $P V R$ SNP rs35385129, but no association with a single intronic PVRL2 SNP analyzed (Pezzetti et al., 2007). 
In the present study, we carried out mutation analyses of PVR and PVRL2 in USA Caucasian (CEU) patients with nsCLP and non-cleft controls. We obtained genomic DNA samples with informed consent from USA patients with nsCLP but with no other physical or cognitive abnormalities, and from unaffected controls. We initially screened all 8 exons of $P V R$ and 10 exons of $P V R L 2$ (encompassing all known mRNA isoforms, except the last $21 \mathrm{nt}$ of PVRL2 exon 1) in 73 unrelated USA CEU nsCLP patients and 105 unrelated USA CEU controls. Subsequently, an additional 28 unrelated USA CEU nsCLP patients were specifically analyzed for the $P V R$ rs1058402 (A67T) variant. The $P V R$ and PVRL2 PCR primers used are given in Table 1. PCR products were screened for variation by simultaneous single-stranded conformation polymorphism (SSCP)/heteroduplex analysis by electrophoresis in 0.5X MDE gels (Biowhittaker Molecular Applications) containing 10\% glycerol (Lee et al., 1995), followed by DNA sequence analysis of those amplicons exhibiting aberrant SSCP/heteroduplex patterns.

As shown in Table 2, we identified a total of four variants in PVR: rs11540085 (-1C > T), rs1058402 (A67T), rs203710 (I340M), and one novel variant, 19:49856876G > A (E404E). Similarly, we identified a total of five variants in PVRL2: rs41290128 (D496N), rs283814 (P409P) and three novel variants, 19:50077328G > A (A355T), 19:50081289T > C $\quad$ (F440F) and 19:50073660_50073661insAGG (R461-462ins). Most variants were observed in both patients and controls, except for the rare variant PVR 19:49856876G > A (E404E), which was observed in only one control, PVRL2 19:50077328G > A (A355T) and 19:50081289T > C (F440F), which we only observed in one and two patients, respectively, and 19:50073660_50073661insAGG (R461$462 \mathrm{ins}$ ), which was observed in two controls. The allele frequency of the non-synonymous $P V R$ variant, rs 1058402 (A67T), in spite of being somewhat greater among nsCLP patients (0.039) than among controls (0.014), did not achieve statistical significance $(p=0.098)$. Likewise, genotype frequency distribution of the rs 1058402 variant was not significantly different between nsCLP patients and controls.

The etiology of orofacial clefts is complex, most likely involving many different genetic and environmental factors, most of which remain unknown. Genetic association and linkage, besides studies, have implicated a region in chromosome $19 \mathrm{q} 13$, termed $O F C 3$. Warrington et al. (2006) reported genetic association between nsCLP and a rare intronic variant in $P V R$, rs 35385129 , in two distinct populations, although no association was found in two other patient groups (Warrington et al., 2006; Pezzetti et al., 2007). In spite of the statistically non-significant results here reported, our data suggest that $P V R$ may bear further investigation.

Table 1 - Oligonucleotide primers for PCR amplification of the exons of PVR and PVRL2.

\begin{tabular}{|c|c|c|c|c|c|}
\hline Amplicon & Primer sequences & $\begin{array}{l}\text { Amplicon } \\
\text { size (bp) }\end{array}$ & Amplicon & Primer sequences & $\begin{array}{c}\text { Amplicon } \\
\text { size (bp) }\end{array}$ \\
\hline \multicolumn{3}{|l|}{$P V R$} & \multicolumn{3}{|l|}{ PVRL2 } \\
\hline Exon 1 & $\begin{array}{l}\text { 5' AGAGCGACGGGCGCCGGGAA 3, } \\
\text { 5, ACTGCGCGGGGGTCACTCAC 3, }\end{array}$ & 165 & Exon 1 & $\begin{array}{l}\text { 5' CTACTAAACCGCCCAGCCGA 3' } \\
\text { 5' CGGTTTCCAGGAGCAGCAGC 3' }\end{array}$ & 169 \\
\hline Exon 2 & $\begin{array}{l}\text { 5' TTCTCTTCGGTTCTCCGCAG 3, } \\
\text { 5, CCCCAAAACCCCCTGCTC 3, }\end{array}$ & 388 & Exon 2 & $\begin{array}{l}\text { 5' GTGGCCCTGCCTGGAGGTGT 3', } \\
\text { 5' TGACCCGCAAGGGGATGCTC 3' }\end{array}$ & 530 \\
\hline \multirow[t]{2}{*}{ Exon 3} & 5, GCTTTTGTTCCTCTTCCCAG 3, & \multirow[t]{2}{*}{337} & Exon 3 & $\begin{array}{l}\text { 5' CTCCTCTGCTGAGTGTTTGT 3, } \\
\text { 5' GTAGACAGTGCTTTAGAGAA 3, }\end{array}$ & 437 \\
\hline & $\begin{array}{l}\text { 5' GCTGACTTGGGCACACTCAC 3' } \\
\text { 5' TCTGTATCCATTTCCTGCAG 3' }\end{array}$ & & Exon 4 & $\begin{array}{l}\text { 5' CTATCTGCTAACTTGTCCAC 3, } \\
5 \text {, TTAGATCCAGGAGTCCAGGC 3, }\end{array}$ & 258 \\
\hline Exon 4 & 5' CCCTGAGACCCAGGACTCAC 3' & 158 & Exon 5 & $\begin{array}{l}5, \text { TCTTTAGGGATGAGGCCTGTG 3, } \\
\text { 5, AAGTCCTGAAGGGCAGAACT 3, }\end{array}$ & 290 \\
\hline Exon 5 & 5' CCACCCAGGGAGTTCCTCAC 3, & 189 & Exon 6 & 5', CCCAGAGCGATCCTCGTGAT 3, & 550 \\
\hline Exon 6 & $\begin{array}{l}\text { 5' CCTGTTTCCTTCTCTTTCAG 3', } \\
\text { 5' GTAGGTGCTCAATTACGGCA 3, }\end{array}$ & 216 & Exon 7 & 5' GATGGTCGCTTGGAATAAGG 3' & 295 \\
\hline Exon 7 & $\begin{array}{l}\text { 5' TTCCCCTCCTATTTCCCCAG 3', } \\
\text { 5' AGCTCCAACACTGCACTTAC 3' }\end{array}$ & 72 & Exon 8 & $\begin{array}{l}\text { 5' GTGCCATAACCCCGGAGTCA 3, } \\
5, \text { GCCAGGCCCCTCCCAGCCCT 3, }\end{array}$ & 205 \\
\hline \multirow[t]{2}{*}{ Exon 8} & $\begin{array}{l}\text { 5' ATTTGAAAACCCTCTTCTAG 3', } \\
\text { 5' GGTCCAACTCTGGAGGCCCA 3, }\end{array}$ & 158 & Exon 9 & $\begin{array}{l}\text { 5' GGCCTGGCAGGGAGAAGCTG 3, } \\
\text { 5' TTGCCAGGCTTGACCCCTGG 3' }\end{array}$ & 228 \\
\hline & & & Exon 10 & $\begin{array}{l}\text { 5' AAGAGCAGATTGGTAATCTG 3' } \\
\text { 5' GGCACTAGATCCTTGGCAAG 3' }\end{array}$ & 411 \\
\hline
\end{tabular}


Table 2 - PVR and PVRL2 variants observed in USA CEU nsCLP patients and controls.

\begin{tabular}{|c|c|c|c|c|c|c|c|c|c|c|}
\hline \multirow[t]{3}{*}{ Variants* } & \multicolumn{3}{|c|}{ Allele frequency } & \multicolumn{7}{|c|}{ Genotype frequency*** } \\
\hline & \multirow[t]{2}{*}{ Cases } & \multirow[t]{2}{*}{ Controls } & \multirow[t]{2}{*}{ p-value** } & \multicolumn{3}{|c|}{ Cases } & \multicolumn{3}{|c|}{ Controls } & \multirow[t]{2}{*}{ p-value*** } \\
\hline & & & & 11 & 12 & 22 & 11 & 12 & 22 & \\
\hline \multicolumn{11}{|l|}{$P V R$} \\
\hline $\begin{array}{l}\text { rs11540085 } \\
(-1 C>T)\end{array}$ & $\begin{array}{l}1 / 146 \\
(0.007)\end{array}$ & $\begin{array}{l}1 / 210 \\
(0.005)\end{array}$ & 0.653 & 72 & 1 & 0 & 102 & 3 & 0 & 0.645 \\
\hline $\begin{array}{l}\text { rs1058402 } \\
(\mathrm{A} 67 \mathrm{~T})\end{array}$ & $\begin{array}{l}8 / 202 \\
(0.039)\end{array}$ & $\begin{array}{l}3 / 210 \\
(0.014)\end{array}$ & 0.098 & 94 & 6 & 1 & 102 & 3 & 0 & 0.245 \\
\hline $\begin{array}{l}\text { rs } 203710 \\
\text { (I340M) }\end{array}$ & $\begin{array}{l}4 / 146 \\
(0.027)\end{array}$ & $\begin{array}{l}3 / 206 \\
(0.015)\end{array}$ & 0.317 & 69 & 4 & 0 & 100 & 3 & 0 & 0.451 \\
\hline $\begin{array}{l}\text { 19:49856876G }>A \\
(\mathrm{E} 404 \mathrm{E})\end{array}$ & $\begin{array}{l}0 / 146 \\
(0)\end{array}$ & $\begin{array}{c}1 / 178 \\
(0.006) \\
\end{array}$ & 0.549 & 73 & 0 & 0 & 88 & 1 & 0 & 1.000 \\
\hline \multicolumn{11}{|l|}{$P V R L 2$} \\
\hline $\begin{array}{l}\text { 19:50077328G }>A \\
(\mathrm{~A} 355 \mathrm{~T})\end{array}$ & $\begin{array}{c}1 / 144 \\
(0.007)\end{array}$ & $\begin{array}{l}0 / 144 \\
(0)\end{array}$ & 0.500 & 71 & 1 & 0 & 72 & 0 & 0 & 1.000 \\
\hline $\begin{array}{l}\text { rs } 283814 \\
\text { (P409P) }\end{array}$ & $\begin{array}{c}3 / 144 \\
(0.068)\end{array}$ & $\begin{array}{c}1 / 144 \\
(0.007)\end{array}$ & 0.311 & 69 & 3 & 0 & 71 & 1 & 0 & 0.620 \\
\hline $\begin{array}{l}\text { 19:50081289T }>C \\
(\mathrm{~F} 440 \mathrm{~F})\end{array}$ & $\begin{array}{l}2 / 144 \\
(0.027)\end{array}$ & $\begin{array}{l}0 / 202 \\
(0)\end{array}$ & 0.173 & 70 & 2 & 0 & 101 & 0 & 0 & 0.172 \\
\hline $\begin{array}{l}\text { 19:50073660_50073661insAGG } \\
\text { (R461-462ins) }\end{array}$ & $\begin{array}{l}0 / 146 \\
(0)\end{array}$ & $\begin{array}{l}2 / 206 \\
(0.001)\end{array}$ & 0.342 & 73 & 0 & 0 & 101 & 2 & 0 & 0.512 \\
\hline $\begin{array}{l}\text { rs } 41290128 \\
(\mathrm{D} 496 \mathrm{~N})\end{array}$ & $\begin{array}{l}2 / 144 \\
(0.027)\end{array}$ & $\begin{array}{c}2 / 202 \\
(0.001)\end{array}$ & 0.553 & 70 & 2 & 0 & 99 & 2 & 0 & 1.000 \\
\hline
\end{tabular}

*Nucleotide positions are referent to NCBI Build 36 (November, 2005), release 38 (April, 2006).

**2X2 Fisher's exact test, 1-tailed assuming that the minor allele tags a potential risk variant.

***For each SNP, the major allele was designated 1 and the minor allele was designated 2; 2X3 Freeman-Halston extension of Fisher's exact test, 2-tailed.

p-values are given without Bonferroni correction.

\section{Acknowledgments}

This work was supported by National Institutes of Health grant DE13571 to R.A.S. We thank Drs. Iain McIntosh and Jeff Murray for contributing patient samples.

\section{References}

Amos C, Gasser D and Hecht JT (1996) Nonsyndromic cleft lip with or without cleft palate: New BCL3 information. Am J Hum Genet 59:743-744.

Avila JR, Jezewski PA, Vieira AR, Orioli IM, Castilla EE, Christensen K, Daack-Hirsch S, Romitti PA and Murray JC (2006) PVRL1 variants contribute to non-syndromic cleft lip and palate in multiple populations. Am J Med Genet 140:2562-2570.

Blanco R, Suazo J, Santos JL, Paredes M, Sung H, Carreño H and Jara L (2004) Association between 10 microsatellite markers and nonsyndromic cleft lip palate in the Chilean population. Cleft Palate Craniofac J 41:163-167.

Cobourne MT (2004) The complex genetics of cleft lip and palate. Eur J Orthod 26:7-16.

Gaspar DA, Matioli SR, Pavanello RC, Araujo BC, Andre M, Steman S, Otto PA and Passos-Bueno MR (2002) Evidence that BCL3 plays a role in the etiology of nonsyndromic oral clefts in Brazilian families. Genet Epidemiol 23:364-374.
Lee ST, Park SK, Lee KH, Holmes SA and Spritz RA (1995) A non-radioactive method for simultaneous detection of single-strand conformation polymorphisms (SSCPs) and heteroduplexes. Mol Cells 5:668-672.

Maestri NE, Beaty TH, Hetmanski J, Smith EA, McIntosh I, Wyszynski DF, Liang KY, Duffy DL and VanderKolk C (1997) Application of transmission disequilibrium tests to nonsyndromic oral clefts: Including candidate genes and environmental exposures in the models. Am J Med Genet 73:337-344.

Marazita ML, Field LL, Cooper ME, Tobias R, Maher B S, Peanchitlertkajorn S and Liu YE (2002) Nonsyndromic cleft lip with or without cleft palate in China: Assessment of candidate regions. Cleft Palate Craniofac J 39:149-156.

Murray JC (2002) Gene/environment causes of cleft lip and/or palate. Clin Genet 61:248-256.

Pezzetti F, Palmieri A, Martinelli M, Scapoli L, Arlotti M, Baciliero U, Padula E, Carinci P, Caramelli E and Carinci F (2007) Linkage disequilibrium analysis of two-genes mapping on OFC3: PVR and PVRL2. Eur J Hum Genet 15:992-994.

Scapoli L, Palmieri A, Martinelli M, Vaccari C, Marchesini J, Pezzetti F, Baciliero U, Padula E, Carinci P and Carinci F (2006) Study of the PVRL1 gene in Italian nonsyndromic cleft lip patients with or without cleft palate. Ann Hum Genet 70:410-413. 
Sözen MA, Suzuki K, Tolarova MM, Bustos T, Fernández Iglesias JE and Spritz RA (2001) Mutation of PVRL1 is associated with sporadic, non-syndromic cleft lip/palate in northern Venezuela. Nat Genet 29:141-142.

Spritz RA (2001) The genetics and epigenetics of orofacial clefts. Curr Opin Pediatr 13:556-560.

Stein J, Mulliken JB, Stal S, Gasser DL, Malcolm S, Winter R, Blanton SH, Amos C, Seemanova E and Hecht JT(1995) Nonsyndromic cleft lip with or without cleft palate: Evidence of linkage to BCL3 in 17 multigenerational families. Am J Hum Genet 57:257-272.

Suzuki K, Hu D, Bustos T, Zlotogora J, Richieri-Costa A, Helms JA and Spritz RA (2000) Mutations of PVRL1, encoding a cell-cell adhesion molecule/herpesvirus receptor, in cleft lip/palate-ectodermal dysplasia. Nat Genet 25:427-430.

Tongkobpetch S, Suphapeetiporn K, Siriwan P and Shotelersuk V (2008) Study of the poliovirus receptor related-1 gene in Thai patients with non-syndromic cleft lip with or without cleft palate. Int J Oral Maxillofac Surg 37:550-553.

Turhani D, Item CB, Watzinger E, Sinko K, Watzinger F, Lauer G and Ewers R (2005) Mutation analysis of CLPTM 1 and
PVRL1 genes in patients with non-syndromic clefts of lip, alveolus and palate. J Craniomaxillofac Surg 33:301-306.

Vanderas AP (1987) Incidence of cleft lip, cleft palate, and cleft lip and palate among races: A review. Cleft Palate J 24:216225.

Warrington A, Vieira AR, Christensen K, Orioli IM, Castilla EE, Romitti PA and Murray JC (2006) Genetic evidence for the role of loci at $19 \mathrm{q} 13$ in cleft lip and palate. J Med Genet 43:e26.

Young JS, Guttman JA, Vaid KS and Vogl AW (2009) Tubulobulbar complexes are intercellular podosome-like structures that internalize intact intercellular junctions during epithelial remodeling events in rat testes. Biol Reprod 80:162-174.

Yoshiura K, Machida J, Daack-Hirsch S, Patil SR, Ashworth LK, Hecht JT and Murray JC (1998) Characterization of a novel gene disrupted by a balanced chromosomal translocation $\mathrm{t}(2 ; 19)(\mathrm{q} 11.2 ; \mathrm{q} 13.3)$ in a family with cleft lip and palate. Genomics 54:231-240.

Associate Editor: Paulo A. Otto

License information: This is an open-access article distributed under the terms of the Creative Commons Attribution License, which permits unrestricted use, distribution, and reproduction in any medium, provided the original work is properly cited. 